\title{
Peningkatan Pendapatan Pengrajin melalui Produksi Briket Ramah Lingkungan
}

\author{
Increasing Craftsmen's Income through Eco-Friendly Briquette Production
}

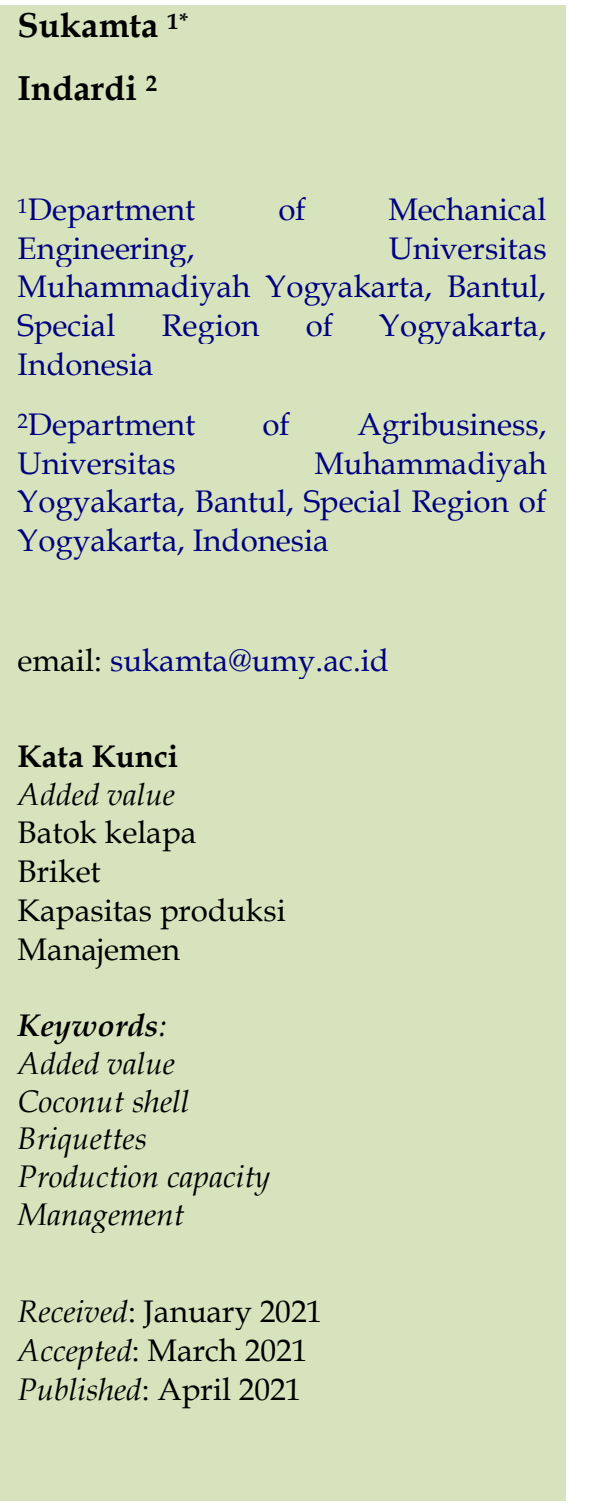

\begin{abstract}
Abstrak
Permasalahan dihadapi pengrajin arang batok kelapa ini adalah manajemen kapasitas produksi, kualitas produk, dan harga jual yang rendah. Kualitas produk yang rendah disebabkan belum adanya penerapan standar mutu di dalam proses produksi. Kegiatan ini bertujuan meningkatkan kualitas manajemen dan added value pada produk arang dengan membuatnya menjadi briket sehingga harga jualnya naik. Metode pelaksanaan kegiatan dibagi dalam dua bidang permasalahan yang berbeda yang ditangani pada satu mitra, yaitu permasalahan produksi dan permasalahan manajemen (manajemen bahan baku, manajemen proses produksi, manajemen packing dan pergudangan, manajemen pengiriman, manajemen penjaminan mutu produk, dan manajemen pemasaran). Luaran kegiatan pengabdian kepada masyarakat ini adalah telah dihasilkan arang batok kelapa dengan kualitas yang meningkat daripada sebelumnya dari sisi kadar air rendah kurang dari $7 \%$. Demikian pula briket yang dihasilkan sudah berkualitas, dan terdapat peningkatan added value melalui pengolahan arang batok menjadi briket telah meningkatkan pendapatan dan laba secara signifikan.
\end{abstract}

\begin{abstract}
The problems faced by coconut shell charcoal craftsmen are production capacity, product quality, and low selling prices. Low product quality is due to the absence of quality standards in the production process. This activity aims to improve the management quality and add value to charcoal products by turning them into briquettes to increase the selling price. Implementing activities is divided into two different problem areas that one partner handles: production problems and management problems (raw material management, production process management, packing, and warehousing management, shipping management, product quality assurance management, and marketing management). The output of this community service activity is that coconut shell charcoal has been produced with an increased quality than before in terms of the low water content of less than $7 \%$. Likewise, the briquettes to those produced were high quality. There was an increase in added value through processing shell charcoal into briquettes which have significantly increased revenue and profit.
\end{abstract}

(C) 2021 Sukamta, Indardi. Published by Institute for Research and Community Services Universitas Muhammadiyah Palangkaraya. This is Open Access article under the CC-BY-SA License (http://creativecommons.org/licenses/by-sa/4.0/). DOI: https://doi.org/10.33084/pengabdianmu.v6i3.2083

\section{PENDAHULUAN}

Kelompok Pengrajin arang batok kelapa "Maju Adil Makmur" terletak di Triharjo, Sleman, Yogyakarta, berdiri tahun 2015 dipimpin oleh Agus Winarno dibantu oleh 4 orang sebagai anggota. Manajemen pengelolaan usaha masih bersifat konvensional dan belum melibatkan teknologi modern. Tingkat Pendidikan para sumberdaya manusianya secara umum berpendidikan setingkat SLTA ke bawah. Ketersediaan bahan baku cukup melimpah yang berasal dari daerah sekitar khususnya wilayah kabupaten Sleman. Kelompok ini 
hanya memiliki dua buah tungku dengan kapasitas 1 Ton/hari batok kelapa atau 24 Ton/bulan bahan baku batok kelapa yang menghasilkan 6,8 Ton/bulan produk arang dengan kadar kekeringan sekitar $7 \%$ atau kadang lebih. Gambaran situasi mitra yaitu kelompok pengrajin "Maju Adil Makmur" dapat dilihat pada Gambar 1 dan 2.

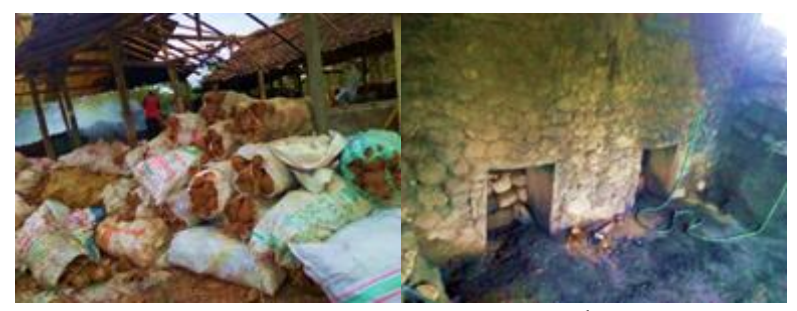

a b

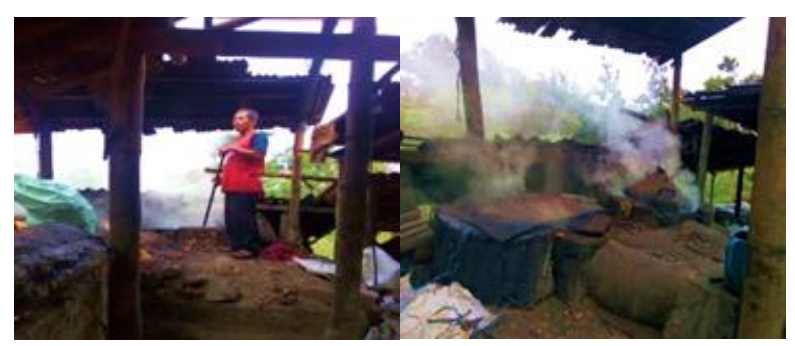

C

d

Gambar 1. (a). Bahan baku batok kelapa, (b). Tungku proses produksi dilihat dari depan, (c). Situasi tempat produksi, (d). Tungku sedang beroperasi dilihat dari bagian atas.

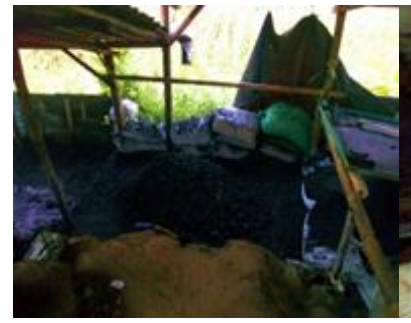

a

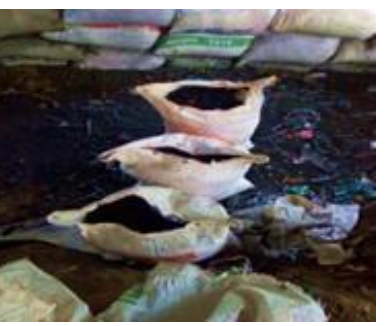

b
Gambar 2. (a). Hasil produksi arang sebelum diayak, (b). Hasil produksi arang setelah diayak dan dikemas.

Untuk satu kali proses produksi membutuhkan waktu kurang lebih 16 jam, sehingga dalam satu hari hanya dapat beroperasi satu kali untuk setiap tungku. Kelompok ini memiliki dua buah tungku sehingga dalam satu hari dapat melakukan proses produksi dengan dua tungku secara bersamaan. Selama ini mulai dari mencari bahan baku, proses produksi, dan penjualan sudah berjalan, namun belum efektif sehingga hasilnya belum dapat maksimal. Kemampuan manajemen ketua kelompok dan anggota kelompok juga relatif rendah karena rerata hanya memiliki latar belakang Pendidikan Sekolah menengah pertama dan atas. Sementara itu, penelitian sebelumnya (Tirono \& Sabit, 2011) melaporkan bahwa tempurung kelapa dapat diolah menjadi arang yang merupakan bahan baku pembuatan arang briket dengan proses karbonisasi. Temperatur karbonisasi sangat berpengaruh terhadap arang yang dihasilkan sehingga penentuan temperatur yang tepat akan menentukan kualitas arang (Jamilatun et al., 2015).

Penelitian sebelumnya terkait penentuan nilai kalor dari arang tempurung kelapa dengan suhu pengarangan yang berbeda. Variasi suhu pengarangan yang diberikan yaitu 200, 250, 300, 350, 400, 500, dan $550^{\circ} \mathrm{C}$, dengan pengulangan sebanyak tiga kali pada setiap variasi suhu. Penelitian tersebut bertujuan untuk mengetahui pengaruh suhu pada proses pengarangan terhadap nilai kalor arang. Hasil penelitian tersebut menunjukkan bahwa penyusutan massa dan nilai kalor berbanding lurus dengan tingginya suhu pengarangan. Semakin tinggi suhu pengarangan, penyusutan massa bahan semakin tinggi dan nilai kalor semakin besar (Tirono \& Sabit, 2011).

Arang juga dapat digunakan untuk pembuatan membran keramik berpori seperti yang telah dilakukan oleh Sandra et al. (2014). Sedangkan efektifitas pemanfaatan ukuran arang batok kelapa sebagai media penyaring terhadap penurunan kadar besi pada air kolam dengan ukuran $6 \mathrm{~cm}$, dan mangan dengan ukuran $9 \mathrm{~cm}$ pernah diteliti oleh Ikhwan (2014). Berdasarkan hasil penelitian tersebut maka disarankan bagi masyarakat umum dan khususnya masyarakat dapat mengupayakan kualitas air secara fisika dan kimia dengan menggunakan filter yang berasal dari arang tempurung kelapa. Selain dapat dibuat briket, arang 
batok kelapa juga dapat dibuat arang aktif (Wulandari et al., 2015).

Potensi ekspor arang batok kelapa sangat terbuka, dan pernah dilakukan oleh Kabupaten Banyumas (Sari, 2011). Sementara itu, pengolahan cangkang kelapa sawit sebagai arang aktif adalah salah satu cara mudah untuk menambah nilai ekonomis. Pemanfaatan arang aktif dalam bidang industri sangat banyak, diantaranya sebagai desulfurisasi pada pemurnian gas dan pengolahan LNG, bahan pembantu proses penyaringan dan lain-lain (Kurniati, 2008).

Permasalahan-permasalahan yang sering dihadapi adalah manajemen kapasitas produksi, kualitas produk, dan harga jual yang rendah. Kapasitas produksi rendah yaitu hanya mampu 0.5 Ton/hari/tungku disebabkan karena terbatasnya jumlah tungku yang dimiliki (hanya ada 2 tungku). Sedang kualitas produk yang rendah disebabkan belum adanya penerapan standar mutu di dalam proses produksi. Sedangkan harga jual sangat dipengaruhi oleh kualitas produk (Machmud, 2011). Oleh karena itu, ada beberapa alternatif penyelesaian untuk mengatasi hal ini, antara lain melalui penerapan standar kualitas arang dengan menurunkan kadar air hingga di bawah 7\% untuk itu diperlukan alat ukur kadar air untuk memastikan produk memenuhi standar. Sedangkan alternatif yang kedua adalah dengan menambahkan proses lanjutan setelah menjadi arang, yaitu memproses arang menjadi briket. Untuk itu, kegiatan pengabdian kepada masyarakat ini bertujuan untuk meningkatkan kualitas manajemen meliputi manajemen bahan baku, manajemen proses produksi, manajemen packing dan pergudangan, manajemen pengiriman, manajemen penjaminan mutu produk, dan manajemen pemasaran.

Selain itu, kegiatan pengabdian kepada masyarakat ini juga bertujuan untuk meningkatkan added value pada produk arang dengan membuatnya menjadi briket ramah lingkungan sehingga harga jualnya naik. Untuk itu dilakukan beberapa hal, diantaranya penyuluhan dengan luaran terjadinya peningkatan pemahaman dari anggota kelompok pengrajin, dilanjutkan dengan pelatihan manajemen bahan baku, proses produksi, packing, pergudangan, pengiriman, jeminan mutu produk, dan pemasaran. Hasil luaran dari pelatihan ini akan menghasilkan peningkatan kapasitas manajemen dan peningkatan skill/keterampilan pembuatan arang dan briket serta kesadaran akan pentingnya kualitas produk dan kepuasan pelanggan (Sa'diyah \& Baga, 2016).

Selanjutnya dilanjutkan dengan proses pendampingan yang efektif kepada anggota kelompok pengrajin agar menghasilkan produk arang yang memenuhi persyaratan standar, serta mampu membuat briket dari arang batok kelapa yang memenuhi persyaratan standar ekspor. Penjaminan mutu produk dilakukan dengan menerapkan standar kualitas dengan mengukur kadar air dalam arang harus kurang dari 7\%. Hal ini juga memerlukan pembelian alat ukur kadar air dan pelatihan penggunaannya oleh karyawan. Terkait dengan proses produksi briket yang memenuhi standar kualitas, pengabdi bersama dengan tim peneliti lainnya telah memiliki pengalaman melakukan kajian tentang karakteristik pembakaran briket kokas lokal pada beberapa temperatur karbonasi. Kesimpulan dari penelitian tersebut adalah bahwa temperatur karbonasi memiliki pengaruh yang signifikan terhadap karakteristik pembakaran dan karakterisasi mekanik briket kokas local. Sehingga hal ini harus menjadi perhatian utama dalam produksi arang dan briket dari batok kelapa ini (Setiabudi et al., 2006). Setelah mampu menghasilkan produk sesuai standar maka akan lebih mudah untuk memasarkannya, apalagi mampu mengolahknya menjadi briket akan semakin mudah memasarkan karena permintaan pasar masih luar dan 
besar. Di samping itu, peningkatan added value melalui pengolahan arang batok menjadi briket akan meningkatkan pendapatan secara signifikan.

\section{METODOLOGI}

Metode pelaksanaan kegiatan pada dua bidang permasalahan yang berbeda yang ditangani pada satu mitra, yaitu permasalahan produksi dan manajemen. Terkait permasalahan produksi maka penyuluhan kepada kelompok pengrajin dilakukan agar bertambah wawasannya dan kemudian mau mengadopsi ide perbaikan ini. Kemudian dilakukan pelatihan proses produksi arang batok kelapa berkualitas, produksi briket, penjaminan kualitas produk dan pelatihan manajemen. Pendampingan efektif secara langsung kepada pengrajin untuk memroduksi arang berkualitas dengan kadar air rendah kurang dari 7\%.

Selanjutnya dilakukan pendampingan pembuatan briket kepada pengrajin agar mampu menghasilkan briket berkualitas dengan target total kapasitas minimal $40 \%$ dari produk arang. Terkait dengan permasalahan manajemen maka dilakukan metode pendampingan manajemen mulai dari manajemen bahan baku, manajemen proses produksi, manajemen packing dan pergudangan, manajemen pengiriman, manajemen penjaminan mutu produk, dan manajemen pemasaran. Sementara, pengukuran keberhasilan implementasi program penting dilakukan untuk mengetahui seberapa berhasil program dan kegiatan yang telah dilakukan, apakah sesuai dengan rencana atau tidak, apa saja kendala yang dihadapi dan apa rencana tindaklanjutnya. Monitoring dan evaluasi sangat penting dilakukan untuk mengetahui kendala-kendala selama proses pelaksanaan dan untuk menjamin keberlangsungan program setelah pengabdian kepada masyarakat ini selesai dilaksanakan.

\section{HASIL DAN PEMBAHASAN}

Pelaksanaan kegiatan terkait dibagi dalam dua bidang permasalahan yang berbeda yang ditangani pada satu mitra, meliputi Permasalahan Produksi dan manajemen. Penyuluhan kepada kelompok pengrajin agar bertambah wawasannya dan kemudian mau mengadopsi ide perbaikan ini. Penyuluhan kepada kelompok pengrajin arang batok "Maju Adil Makmur" telah dilaksanakan pada bulan hari Sabtu, 2 Mei 2020 pukul 09.00 WIB bertempat di rumah ketua kelompok pengrajin arang batok kelapa "Maju Adil Makmur" yang beralamat di Dusun Murangan 7, Desa Triharjo, Sleman, Yogyakarta, seperti ditunjukkan pada Gambar 3.

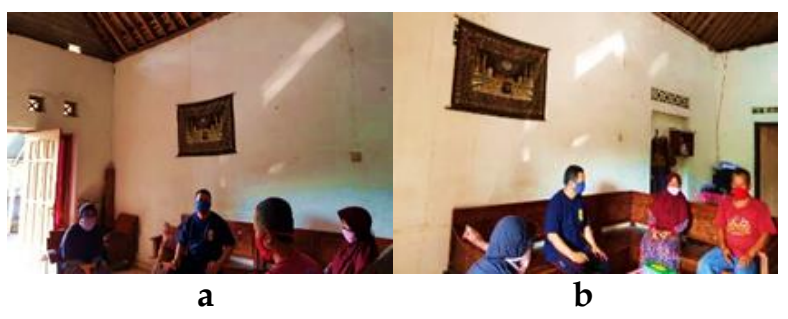

Gambar 3. (a). Sosialisasi dan (b) penyuluhan kepada kelompok pengrajin arang batok "Maju Adil Makmur".

Pelatihan proses produksi arang batok kelapa berkualitas, produksi briket, penjaminan kualitas produk dan pelatihan manajemen. Selanjutnya dilakukan pelatihan proses produksi arang batok kelapa berkualitas, dilanjutkan dengan pelatihan pembuatan briket, dan pelatihan penjaminan kualitas produk, serta pelatihan manajemen secara singkat pada hari Sabtu 9 Mei 2020 dan hari Minggu 10 Mei 2020 mulai pukul 09.00 WIB sampai selesai, seperti ditunjukkan pada Gambar 4.

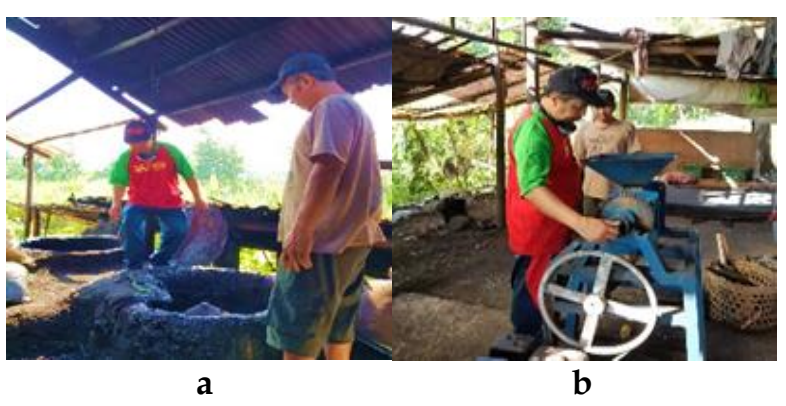

Gambar 4. Pelatihan langsung di lapangan untuk pembuatan (a) arang batok dan (b) briket 
Pendampingan efektif secara langsung kepada pengrajin untuk memproduksi arang berkualitas dengan kadar air rendah kurang dari 7\% ditunjukkan pada Gambar 5.

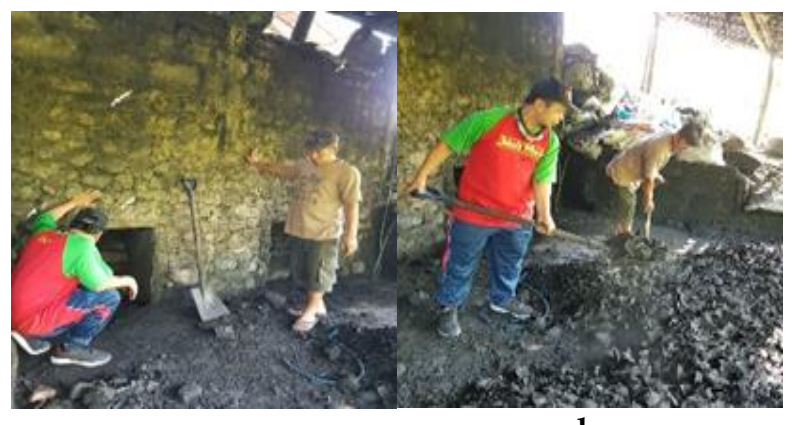

a

b

Gambar 5. (a). Pendampingan Pengaturan Tungku Batok kelapa agar pembakaran sempurna dan (b) Pendampingan untuk memilah hasil arang batok kelapa yang baru saja dikeluarkan dari tungku

Pendampingan pembuatan briket kepada pengrajin agar mampu menghasilkan briket berkualitas dengan target total kapasitas minimal $40 \%$ dari produk arang ditunjukkan pada Gambar 6.

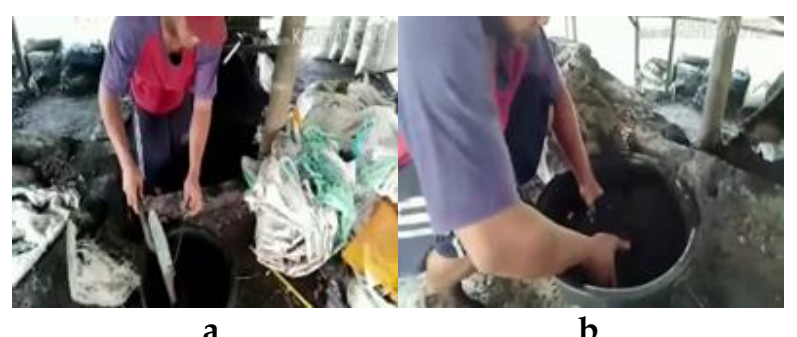

Gambar 5. Pendampingan pembuatan briket, meliputi (a). Pencampuran arang batok yang lembut dengan pathi kanji serta air secukupnya dan (b) Pengadukan awal sebelum menggunakan mixer

Video pendampingan pembuatan briket selengkapnya dapat dilihat pada tautan youtube berikut:

https://www.youtube.com/watch?v=H5TdWjLqTuM

Permasalahan Manajemen diantaranya meliputi Manajemen Bahan Baku, Manajemen Proses produksi, manajemen packing dan pergudangan, manajemen pengiriman, manajemen penjaminan mutu produk, dan manajemen pemasaran. Untuk itu dilakukan metode pelaksanaan pendampingan manajemen mulai dari manajemen bahan baku, manajemen proses produksi, manajemen packing dan pergudangan, manajemen pengiriman, manajemen penjaminan mutu produk, dan manajemen pemasaran. Selain itu, juga dilakukan pengukuran keberhasilan implementasi program. Hal ini penting untuk mengetahui seberapa berhasil program dan kegiatan yang telah dilakukan, apakah sesuai dengan rencana atau tidak, apa saja kendala yang dihadapi dan apa rencana tindaklanjutnya.

Hasil atau luaran kegiatan pengabdian kepada masyarakat ini adalah telah dihasilkan arang batok kelapa dengan kualitas yang meningkat daripada sebelumnya dari sisi kadar air rendah kurang dari $7 \%$. Demikian pula briket kepada yang dihasilkan sudah berkualitas, dengan capaian target total kapasitas minimal $40 \%$ pada akhir bulan September 2020. Sampel produk briket yang dimaksud ditunjukkan pada Gambar 7.

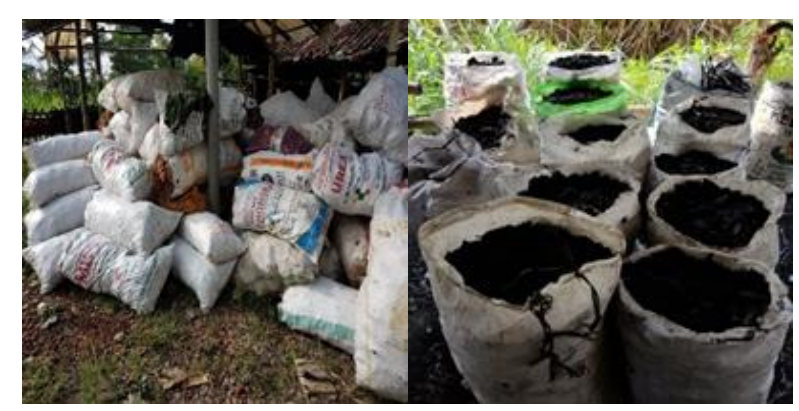

a

b

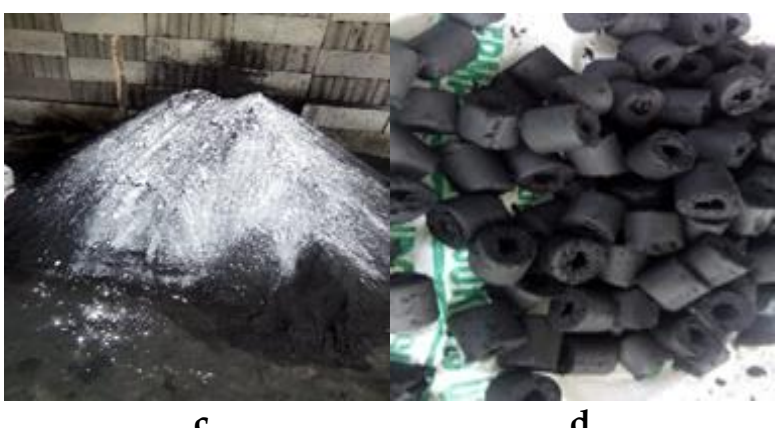

C

d

Gambar 7. (a). Bahan baku batok kelapa, (b). Hasil Arang Batok Kelapa, (c). Pencampuran Arang batok dengan pati kanji dan air, (d). Sampel Hasil Briket.

Dampak ekonomi dan sosial berupa peningkatan pada mitra dilaporkan dalam bentuk data terukur dan dapat disajikan dalam grafik peningkatan pendapatan, biaya operasional, dan laba seperti ditunjukkan pada Gambar 
8 sampai 10. Selama ini, penjualan arang batok kelapa dilakukan kepada sebuah perusahaan tertentu melalui sebuah agen. Maka terobosan ini, pengrajin dapat langsung menjual produk arang batok ini ke perusahaan tanpa melalui sebuah agen/pengepul agar mengurangi rantai penjualan dan akan meningkatkan margin hingga $5 \%$. Di samping itu, peningkatan added value melalui pengolah arang batok menjadi briket akan mingkatkan pendapatan secara signifikan.

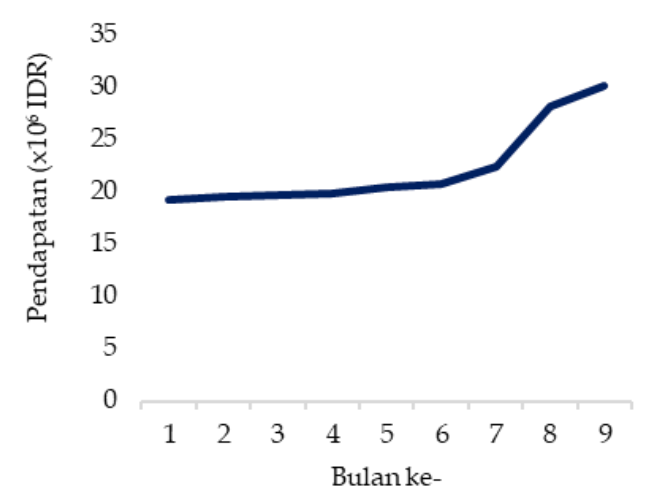

Gambar 8. Pendapatan

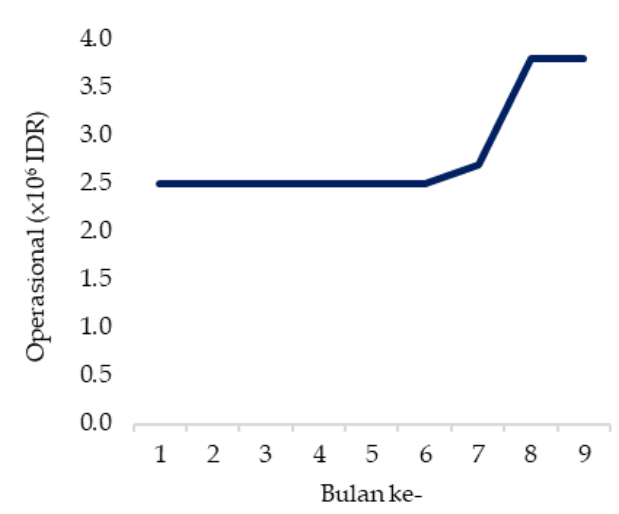

Gambar 9. Biaya operasional

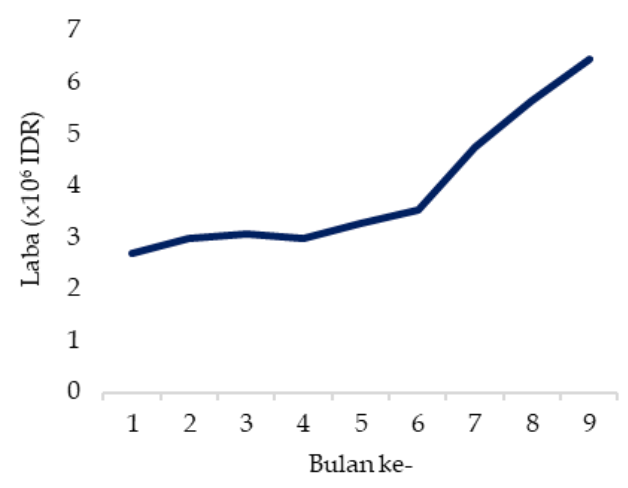

Gambar 10. Perkembangan laba
Sementara itu, kebutuhan akan briket arang oleh negara negara di Eropa, Amerika dan Timur Tengah mendorong permintaan luar negeri yang semakin meningkat, sehingga memunculkan pengusahapengusaha briket arang batok kelapa. Secara umum permasalahan yang dihadapi terkait kualitas sumber daya manusia dalam pengelolaan keuangan dan peningkatan kapasitas produksi. Untuk itu telah dilakukan pemberian pendampingan penggunaan software akuntasi, dan peningkatan kapasitas produksi dengan pengadaan mesin belt conveyor yang dapat menambah menambah kecepatan dan jumlah produksi (Towaha et al., 2013).

Penelitian sejenis yang hampir sama dilakukan oleh Nugroho et al. (2019), yaitu dengan peningkatan kapasitas produksi dengan pembuatan belt conveyor dan oven permanen pada upgrading briket arang batok kelapa. Disamping itu, penelitian tentang penentuan kadar air hilang dan volatile matter pada bio-briket dari campuran arang sekam padi dan batok kelapa telah dilakukan oleh peneliti sebelumnya (Yuliah et al., 2017). Penelitian ini juga menganalisis pengaruhnya terhadap nilai kalor yang dikandungnya. Hasilnya diketahui bahwa briket dengan kadar perekat 4\% dan 10\% memiliki kandungan energi panas tertinggi yaitu sebesar $4132 \mathrm{~kJ} / \mathrm{kg}$.

Aplikasi campuran arang batok kelapa dan bubur kertas dapat digunakan sebagai penyaring emisi gas buah kendaraan bermotor. Gas buang pada sepeda motor sebelum dan sesudah penyaringan oleh campuran arang batok kelapa dapat efektif bekerja dalam mengabsorben karbon. Metode penelitian menggunakan variabel bebas yaitu volume arang dan knalpot motor yang bervariasi. Hasil, ukuran tebal briket arang batok kelapa yang paling efektif untuk absorben gas buang pada sepeda motor adalah $5 \mathrm{~cm}$ (Mahendra et al., 2017). 


\section{KESIMPULAN}

Pengabdian kepada masyarakat ini telah memberikan gambaran hasil yang cukup signifikan berupa peningkatan kualitas arang dengan kedari air kurang dari $7 \%$. Disamping itu, arang yang rendah kualitasnya kemudian dibuat briket dan mampu meningkatkan pendapatan dan laba secara signifikan.

\section{UCAPAN TERIMA KASIH}

Ucapan Terima Kasih Kepada Kementerian Badan Ristek dan Inovasi Nasional, Lembaga Layanan Pendidikan Tinggi Wilayah V, No. Kontrak 805.6/L15/Am/2020 Tanggal 28 Februari 2020. Ucapan terima kasih juga diberikan kepada Kelompok Pengrajin Arang Batok " Maju Adil Makmur", Agus Winarno, Sriyatun, yang memberikan sumbangan berarti dalam program ini.

\section{REFERENSI}

Ikhwan, Z. 2014. Efektivitas Penggunaan Arang Batok Kelapa Sebagai Media Penyaring Penurunan Kadar Besi Dan Mangan Pada Penjernihan Air Kolam Penambangan Batu Bauksit. Jurnal Kesehatan. 5(2):150-153.

http://dx.doi.org/10.26630/jk.v5i2.48

Jamilatun, S., Salamah, S., Isparulita, I.D. 2015. Karakteristik Arang Aktif Dari Tempurung Kelapa Dengan Pengaktivasi H2SO4 Variasi Suhu Dan Waktu. CHEMICA: Jurnal Teknik Kimia. 2(1):13-19. http://dx.doi.org/10.26555/chemica.v2i1.456 2

Kurniati, E. Pemanfaatan Cangkang Kelapa Sawit Sebagai Arang Aktif. Jurnal Penelitian IlmuIlmu Teknik. 8(2):96-103.

Machmud, S. 2011. Kajian Ekonomis Industri Briket Arang Tempurung Kelapa. Jurnal Ekonomi, Bisnis \& Entrepreneurship. 5(1):45-51.

Mahendra, S., Qomaruddin, M., Mulyahati, M.Y. 2017. Studi Penyaring Emisi Pada Knalpot Sepeda Motor Dengan Briket Arang Batok Kelapa.
Traksi: Majalah Ilmiah Teknik Mesin. 17(2):1-7. https://doi.org/10.26714/traksi.17.2.2017.\%2 $5 \mathrm{p}$

Nugroho, H.S., Anita, D.C., Wulandari, R. 2019. Peningkatan Kapasitas Produksi: Pembuatan Belt Conveyor Dan Oven Permanen Pada Upgrading Briket Arang Batok Kelapa. Abdimas: Jurnal Pengabdian Masyarakat Universitas Merdeka Malang. 4(1):37-40. https://doi.org/10.26905/abdimas.v4i1.3237

Sa'diyah, F.N., Baga, L.M. 2016. Perencanaan Bisnis Briket Tempurung Kelapa Berbasis Wirakoperasi Di Kabupaten Bogor. Forum Agribisnis: Agribusiness Forum. 6(1):65-90. https://doi.org/10.29244/fagb.6.1.65-90

Sandra, K.O., Budi, A.S., Susilo, A.B. 2014. Pengaruh Suhu Sintering Terhadap Densitas dan Porositas pada Membran Keramik Berpori Berbasis Zeolit, Tanah Lempung, Arang Batok Kelapa, dan Polyvinylalcohol (PVA). In Prosiding Pertemuan Ilmiah XXVIII HFI Jateng \& DIY. Yogyakarta: Universitas Negeri Yogyakarta. 392-395.

Sari, M.K. 2011. Potensi Dan Peluang Kelayakan Ekspor Arang Tempurung Kelapa (Coconut shell charcoal) Di Kabupaten Banyumas. Mediagro: Jurnal Ilmu-Ilmu Pertanian. 7(2):69-82. http://dx.doi.org/10.31942/md.v7i2.576

Setiabudi, D.H., Himawanto, D.A., Sukamta, S. 2006. Karakteristik Pembakaran Briket Kokas Lokal Pada Beberapa Temperatur Karbonasi. Semesta Teknika. 9(2):103-113.

Towaha, J., Aunillah, A., Purwanto, E.H. 2013. Pemanfaatan Asap Cair Kayu Karet Dan Tempurung Kelapa Untuk Penanganan Polusi Udara Pada Lump. Jurnal Tamanan Industri dan Penyegar (Journal of Industrial and $\begin{array}{lll}\text { Beverage } & \text { Crops). } & 4(1): 71-80 .\end{array}$ http://dx.doi.org/10.21082/jtidp.v4n1.2013.p $71-80$

Tirono, M., Sabit, A. 2011. Efek Suhu Pada Proses Pengarangan Terhadap Nilai Kalor Arang Tempurung Kelapa (Coconut Shell Charcoal). Jurnal Neutrino: jurnal fisika dan aplikasinya. 3(2):143-152.

https://doi.org/10.18860/neu.v0i0.1647

Wulandari, F., Umiatin, Budi, E. 2015. Pengaruh Konsentrasi Larutan $\mathrm{NaOH}$ Pada Karbon 
Aktif Tempurung Kelapa Untuk Adsorpsi Logam Cu2+. Spektra: Jurnal Fisika dan Aplikasinya. 16(2):60-64.

Yuliah, Y., Suryaningsih, S., Ulfi, K. 2017. Penentuan Kadar Air Hilang dan Volatile Matter pada Bio-Briket dari Campuran Arang Sekam Padi dan Batok Kelapa. JIIF (Jurnal Ilmu dan Inovasi Fisika). 1(1):51-57. https://doi.org/10.24198/jiif.v1i01.10902 